\title{
Oxidation of Cobalt(II) Tetraphenylporphyrinate with Molecular Oxygen
}

\author{
Tatyana M. Ziyadova, ${ }^{a}$ Vladimir A. Burmistrov, ${ }^{a, b}$ Alexandr S. Semeikin, ${ }^{a}$ \\ and Oskar I. Koifman ${ }^{\mathrm{a}, \mathrm{b}}$
}

${ }^{a}$ Research Institute of Macroheterocycles, Ivanovo State University of Chemistry and Technology, 153000 Ivanovo, Russian Federation

${ }^{\mathrm{b}}$ G.A. Krestov Institute of Solution Chemistry, Russian Academy of Sciences, 153045 Ivanovo, Russian Federation

${ }^{\circledR}$ Corresponding author E-mail: ziyadova_tm@mail.ru

\begin{abstract}
The state of cobalt complexes with tetraphenylporphyrin in alcoholic solutions has been studied by means of conductometry and electronic absorption spectroscopy. In the presence of oxygen, the Co II complex is oxidized into the $\mu$-peroxodimer and chloro(tetraphenylporphyrinato)cobalt(III), the latter exists in the form of the solvent-separated ion pair. Kinetic experiments have revealed conditions of the products formation in the course of the Co ${ }^{I I}$ complex oxidation. It has been demonstrated that only chloro(tetraphenylporphyrinato)cobalt(III) oxidizes thiols in the presence of oxygen. The elucidated kinetic and activation parameters of the $\mathrm{Co}^{I I}+\mathrm{O}_{2} \rightarrow \mathrm{Co}^{I I I}$ reaction have demonstrated that its enthalpy is low and positive, whereas its entropy is high and negative.
\end{abstract}

Keywords: Metalloporphyrin, $\mu$-peroxodimer, oxidation, ion pair.

\section{Окисление тетрафенилпорфирината кобальта(II) молекулярным кислородом}

\author{
Т. М. Зиядова, ${ }^{a} @$ В. А. Бурмистров ${ }_{1}^{\text {a,b }}$ А. С. Семейкин, ${ }^{a}$ О. И. Койфмман ${ }^{\text {a,b }}$ \\ а НИИ макрогетерочиклических соединений, Ивановский государственный химико-технологический университет, \\ 153000 Иваново, Россия \\ ${ }^{\mathrm{b}}$ Институт химии растворов им. Г. А. Крестова РАН, 153045 Иваново, Россия \\ ${ }^{\circledR}$ E-mail: ziyadova_tm@mail.ru
}

\begin{abstract}
Методами кондуктометрии и электронной спектроскопии исследовано состояние кобальтовых комплексов тетрафенилпорфина в спиртовых растворах. Установлено, что при доступе кислорода комплекс двухвалентного кобальта окисляется до н-пероксодимера и хлоридтетрафенилпорфирината Со существуюшего в растворе в виде сольватно разделенной ионной пары. В ходе кинетического эксперимента определены условия образования ц-пероксодимера и хлоридтетрафенилпорфирината Со пII при окислении комплекса Со ${ }^{I I}$. Показано, что только тетрафенилпорфиринат кобальта(III) способен $к$ окислению меркаптанов в отсутствии кислорода. Рассчитаны кинетические и активационные параметры реакции Со $+\mathrm{O}_{2} \rightarrow \mathrm{Co}^{\text {III }}$, свидетельствующие о низкой положительной энтальпии и высокой отрицательной энтропии активации этого процесса.
\end{abstract}

Ключевые слова: Металлопорфирин, $\mu$-пероксодимер, окисление, ионная пара. 


\section{Introduction}

Metal complexes with macroheterocyclic compounds (for instance, porphyrins and phthalocyanines) are of considerable interest for researchers working in the fields of chemistry, biochemistry, and chemical engineering. The interest to such compounds is due to their important part in the biochemical processes. Furthermore, the macroheterocyclic complexes have been widely used in many fields of science and technology, including development of cancer diagnostics and therapy, antiviral blood treatment as well as preparation of dyes, pigments, and various catalysts. Diversity of applications of porphyrins metal complexes is based on their peculiar properties, such as ability to axially coordinate certain small molecules $\left(\mathrm{H}_{2} \mathrm{O}, \mathrm{O}_{2}\right.$, etc.), chemical and thermal stability, chromophoric properties, and so further. [1-3] The complexes catalytic activity is closely related to their redox properties. In view of the above, this work was devoted to study of oxidation of cobalt(II) tetraphenylporphyrinate $\left(\mathrm{Co}^{\mathrm{II}} \mathrm{TPP}\right)$ with oxygen, extending the previously reported results. ${ }^{[4]}$

\section{Experimental}

Cobalt(II) 5,10,15,20-tetraphenylporphyrinate (Co II TPP) was used as model macrocycle. Ethanol $(99.9 \%)$ was used for the solutions preparation.

Co IITPP preparation. $2.0 \mathrm{~g}(3.25 \mathrm{mmol})$ of $5,10,15,20$-tetraphenylporphyrinate was extracted with the Soxhlet apparatus into a boiling solution of $3.0 \mathrm{~g}$ (12.04 mmol) of cobalt(II) acetate tetrahydrate in $150 \mathrm{ml}$ of acetic acid. Then the mixture was cooled down; the precipitate was filtered off, washed with acetic acid and methanol, and dried in air at $70{ }^{\circ} \mathrm{C}$. Yield: $1.8 \mathrm{~g}(81 \%)$. UV-Vis $\left(\mathrm{CHCl}_{3}\right)$ $\lambda \mathrm{nm}(\lg \varepsilon): 529$ (4.18), 411 (5.40).

CoIITP oxidation with oxygen. Oxidation of cobalt(II) tetraphenylporphyrinate was performed as described elsewhere. ${ }^{[4]}$ Concentration of dissolved oxygen was determined using the HQ portable device equipped with the LDO IntelliCALTM detector. Electronic absorption spectra were recorded using the UV-VIS Lambda 20 scanning photometer (Perkin-Elmer), the wavelength setting accuracy being of $\pm 0.1 \mathrm{~nm}$.

Calculation of rate constants, equilibrium constants, activation and thermodynamic parameters of Co IITPP oxidation. The rate constants were defined by two methods. I. The rate constants were calculated taking advantage of the KinCalc software. The rate and equilibrium constants were computed via the least squares method using the following experimentally determined input parameters: initial concentrations of $\mathrm{O}_{2}, \mathrm{HCl}$, and $\mathrm{H}_{2} \mathrm{O}$; concentrations of $\mathrm{Co}^{\mathrm{II}} \mathrm{TPP}$, chloro(tetraphenylporphyrinato)cobalt(III) (ClCo $\left.{ }^{\mathrm{III}} \mathrm{TPP}\right)$, and $\mu$-peroxodimer (D) as functions of the reaction time. The concentrations of $\mathrm{Co}^{\mathrm{II}} \mathrm{TPP}, \mathrm{ClCo}{ }^{\mathrm{III}} \mathrm{TPP}$, and $\mathrm{D}$ were determined from the absorbance data. Molar absorptivities of the molecular forms of the cobalt complexes were previously elucidated via the absorption spectra deconvolution: ${ }^{[4]} \mathrm{UV}-\mathrm{V}$ is $\left(\mathrm{C}_{2} \mathrm{H}_{5} \mathrm{OH}\right) \lambda \mathrm{nm}(\lg \varepsilon)$ : $\mathrm{Co}^{\mathrm{II}} \mathrm{TPP} 411.8$ (4.43); ClCo ${ }^{\mathrm{II}} \mathrm{TPP} 427.4$ (4.83); and D 386 (4.88). II. To calculate the rate constant, we used the program developed $\mathrm{in}^{[5]}$ that including a method of calculation based on the use of optical density measurements over the maximum number of points in the series of spectra obtained by the spectrophotometer, which was capable of automatic digital recording. The error in determing the reaction rate constants does not exceed $5 \%$. The difference between the rate constants determined by these methods does not exceed the error. The activation energy $E_{a}$ and the pre-exponential factor were determined graphically from the $\ln k_{v}=f\left(\mathrm{~T}^{-1}\right)$ plot; other activation parameters (the enthalpy, the entropy, and the Gibbs energy) were determined as described elsewhere. ${ }^{[6]}$ The rate constant of the reaction can be expressed as:

$$
k=\frac{\left(K^{\neq}\right) k_{B} T}{h}
$$

where $K^{\ddagger}$ is the concentration equilibrium constant of activated complex formation; $k_{B}$ is Boltzmann's constant; $h$ is Planck's constant.

In transition state theory, the activation Gibbs energy, $\Delta G^{\neq}$, is defined by:

$$
\Delta G^{\ddagger}=-R T \ln \left(K^{\ddagger}\right),
$$

where $R$ is gas constant.

The enthalpy of activation $\Delta H^{\ddagger}$ and entropy of activation $\Delta S^{\ddagger}$ were calculated as:

$$
\begin{aligned}
& \Delta H^{\neq}=E_{a}-R T \\
& \Delta G^{\neq}=\Delta H^{\neq}-T \Delta S^{\neq}
\end{aligned}
$$

The equilibrium constant $K_{\text {eq }}$ was calculated using the equation: ${ }^{[7]}$

$$
K_{e q}=\frac{A_{\tau}-A_{o}}{A_{\infty}-A_{\tau}} \cdot \frac{1}{C_{l}^{O}-C_{M C}^{O} \cdot \frac{A_{\tau}-A_{O}}{A_{\infty}-A_{\tau}}}
$$

where $A_{o}, A_{\tau}, A_{\infty}$ are optical density of the metallocomplexes solutions at time $0, \tau$ and after the reaction, respectively; $C_{l}^{o}$ is initial concentration of the ligand, $\mathrm{mol} / \mathrm{l} ; C_{M C}{ }^{o}$ is initial concentration of the metallocomplex, $\mathrm{mol} / \mathrm{l}$.

When the reaction is at equilibrium $(\Delta G=0)$ and according to isobar equation:

$$
\Delta G^{0}=-R T \ln \left(K_{e q}\right) .
$$

In thermodynamics, the change in Gibbs free energy, $\Delta G$, is defined as:

$$
\Delta G^{0}=\Delta H^{0}-T \Delta S^{0}
$$

Summary

$$
\ln K_{e q}=\frac{\Delta H^{o}}{R} \cdot \frac{1}{T}+\frac{\Delta S^{o}}{R} .
$$

The thermodynamic parameters of the process (the entropy and the enthalpy) were determined graphically from the $\ln K_{e q}=f\left(T^{-1}\right)$ plot: $\operatorname{tg} \alpha=-\Delta H^{\circ} / R ; A=\Delta S^{\circ} / R$.

Conductometry of the cobalt porphyrinates in ethanolic solutions. Conductometric measurements were performed in the cell equipped with platinum electrodes at $298.15 \pm 0.15 \mathrm{~K}$. The cell was calibrated using the $0.1 \mathrm{~mol} / 1 \mathrm{KCl}$ solution. ${ }^{[8]}$ The cell constant was of $k=0.2118 \mathrm{~cm}^{-1}$. The specific conductivity $\left(\Omega^{-1} \cdot \mathrm{cm}^{-1}\right)$ was calculated as

$$
\chi=k / R
$$

with $R$ being a measured electrical resistance.

In order to precisely calculate the conductance, the conductivity of pure solvent was accounted for. ${ }^{\left[{ }^{[9]}\right.}$ The true value of the solute conductivity was found as the difference between those of the solution and the solvent: 


$$
\chi=\chi_{\text {solution }}-\chi_{\text {solvent }}
$$

The excess molar conductivity $\lambda$ was calculated from the true solute conductivity $\chi$ and the solute concentration $C(\mathrm{~mol} / \mathrm{l})$ :

$$
\lambda=\chi / C
$$

The uncertainty of true solute conductivity and excess molar conductivity determination did not exceed $5 \%$.

\section{Results and Discussion}

As it was shown previously, ${ }^{[4]}$ the dissolved cobalt(II) complex $\mathrm{Co}^{\mathrm{II}} \mathrm{TPP}$ was oxidized into the $\mu$-peroxodimer $\mathrm{Co}^{\mathrm{III}} \mathrm{TPP}-\mathrm{O}-\mathrm{O}-\mathrm{Co}^{\mathrm{III}} \mathrm{TPP}$ (D) and chloro(tetra-phenylpor-

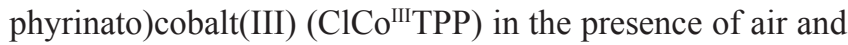
$\mathrm{Cl}^{-}$ions $(\mathrm{KCl}$ or $\mathrm{HCl})$. The electronic absorption studies of $\mathrm{Co}^{\mathrm{II}} \mathrm{TPP}$ oxidation ${ }^{[4]}$ led to reliable estimation of the oxidation state of the complex forming metal (cobalt) in all the complexes forms; however, the complexes dissociation or ion pairs formation could not be elucidated. As the complexes concentration was low $\left(10^{-5}-10^{-6} \mathrm{~mol} / \mathrm{l}\right)$, that could be achieved taking advantage of conductometric measurements.

In view of the above, we have measured the conducti-vity $\chi$ and calculated the excess molar conductivity $\lambda$ of the following ethanolic solutions: Co ${ }^{\mathrm{II}} \mathrm{TPP}$ (under argon), $\mathrm{Co}^{\mathrm{III}} \mathrm{TPP}+$ the $\mu$-peroxodimer, and $\mathrm{Co}^{\mathrm{III}} \mathrm{TPP}$ (in the presence of equimolar concentration of $\mathrm{HCl}$ ). For the sake of comparison we have measured the conductivity of cetyltrimethylammonium bromide CTAB solution, the organic electrolyte is known to exist in the form of free solvated ions in ethanol at concentration of about $10^{-5} \mathrm{~mol} / \mathrm{l}^{[10]}$

The data collected in Table 1 have evidenced that the excess conductivity was close to zero in the case of Co ${ }^{\text {II TPP, }}$ the background value of $0.09 \Omega^{-1} \cdot \mathrm{cm}^{2} \cdot \mathrm{mol}^{-1}$ had apparently caused by the presence of admixtures.

Co ${ }^{\mathrm{II}} \mathrm{TPP}$ oxidation with air oxygen was not accompanied with the conductivity increase (Table 1); hence, the charged particles concentration in the oxidized system was insignificant. Taking into account the presence of the uncharged $\mu$-peroxodimer, it was reasonable to assume that the cobalt(III) complex was not charged as well, and the acidic ligand was either directly bound to the complex forming ion (X-Co ${ }^{\text {III TPP) }}$ or formed the contact ion pair $\left(\mathrm{X}^{\delta-} \mathrm{Co}^{\delta+} \mathrm{TPP}\right)$. Hydroxyl ion formed via the autoprotolysis of water traces could act as the ligand $\mathrm{X}$.

Introduction of the equimolar amount of $\mathrm{HCl}$ into the $\mathrm{Co}^{\mathrm{III}} \mathrm{TPP}$ solution has led to significant increase of the excess

Table 1. Conductivity $\chi$ and excess molar conductivity $\lambda$ of the studied compounds (ethanol at $298.15 \mathrm{~K}$ ).

\begin{tabular}{cccc}
\hline Solute & $C, \mathrm{~mol} / 1$ & $\chi, \Omega^{-1} \cdot \mathrm{cm}^{-1}$ & $\lambda, \Omega^{-1} \cdot \mathrm{cm}^{2} \cdot \mathrm{mol}^{-1}$ \\
\hline $\begin{array}{c}\text { Ethanol } \\
\text { (pure solvent) }\end{array}$ & - & $1.6 \cdot 10^{-7}$ & - \\
$\mathrm{ClCo}^{\text {IIITPP }}$ & $9.08 \cdot 10^{-6}$ & $3.03 \cdot 10^{-4}$ & 33.37 \\
$\mathrm{Co}^{\text {IIITPP }}$ & $8.83 \cdot 10^{-6}$ & $10.53 \cdot 10^{-7}$ & 0.10 \\
Co $^{\text {II TPP }}$ & $9.13 \cdot 10^{-6}$ & $9.63 \cdot 10^{-7}$ & 0.09 \\
(under Ar) & & - & 86.90 \\
CTAB & $1.64 \cdot 10^{-4}$ & - & \\
\hline
\end{tabular}

molar conductivity due to formation of the charged complex. However, the excess conductivity of the $\mathrm{ClCo}^{\text {IIITPP }}$ solution was twice lower than that of the CTAB solution; hence, the cobalt(III) complex in the presence of $\mathrm{Cl}^{-}$ions in ethanol has likely existed in the form of the solvent-separated ion pairs $\mathrm{Cl}^{\delta-}$ (solv) $\mathrm{Co}^{\mathrm{III \delta}+} \mathrm{TPP}$.

It was previously demonstrated ${ }^{[4]}$ that the following equality was held at any reaction time $\tau$ in the course of $\mathrm{Co}^{\mathrm{II}} \mathrm{TPP}$ interaction with oxygen and hydrochloric acid:

$$
\begin{aligned}
& {\left[\mathrm{Co}^{\mathrm{II}} \mathrm{TPP}\right]_{0}=\left[\mathrm{Co}^{\mathrm{II}} \mathrm{TPP}\right]_{\tau}+\left[\mathrm{ClCo}^{\mathrm{III}} \mathrm{TPP}\right]_{\tau}+} \\
& +2\left[\mathrm{Co}{ }^{\mathrm{III}} \mathrm{TPP}-\mathrm{O}-\mathrm{O}-\mathrm{Co}^{\mathrm{III}} \mathrm{TPP}\right]_{\tau} .
\end{aligned}
$$

Hence, the oxidation could be represented by reactions (b) and (c).

$$
\begin{aligned}
& 2 \mathrm{Co}^{\mathrm{II}} \mathrm{TPP}+\mathrm{O}_{2} \rightarrow \mathrm{Co}^{\mathrm{III}} \mathrm{TPP}-\mathrm{O}-\mathrm{O}-\mathrm{Co}^{\mathrm{III}} \mathrm{TPP} \\
& \mathrm{Co}^{\mathrm{II}} \mathrm{TPP}+\mathrm{O}_{2}+\mathrm{Cl}^{-} \rightarrow \mathrm{ClCo}{ }^{\mathrm{II}} \mathrm{TPP}+\mathrm{O}_{2}^{-}
\end{aligned}
$$

In order to compare these stages significance in the course of catalytic oxidation of thiols, we have studied the effect of three forms of cobalt complexes on the oxidation of 1-propanethiol in ethanol. The experiments have revealed that the peroxodimer $\mathrm{D}$, as well as $\mathrm{Co}^{\mathrm{II}} \mathrm{TPP}$ complex, ${ }^{[13]}$ did not oxidize 1-propanethiol, what was confirmed by conclusions made earlier ${ }^{[11,12]}$ ). Only $\mathrm{Co}^{\text {III TPP }}$ is able to oxidize 1-propanethiol rapidly in the oxygen-free solution. Therefore, the reaction (c) is seemed to be important in view of mechanism of catalytic oxidation of thiols. Further kinetic studies of $\mathrm{Co}^{\mathrm{II}} \mathrm{TPP}$ oxidation were performed under conditions of reaction (c) domination. Taking advantage of the specially developed software, we have processed the $\left[\mathrm{Co}^{\mathrm{IITPP}}\right]=f(\tau)$ and $\left[\mathrm{ClCo}^{\mathrm{II}} \mathrm{TPP}\right]=f(\tau)$ kinetic curves and calculated the rate constant of reaction (c) as function of $\mathrm{HCl}$ concentration (Table 2).

Table 2. Rate constants of cobalt(II) tetraphenylporphyrinate oxidation with molecular oxygen in ethanol

$\left(C\left(\mathrm{Co}^{\mathrm{II}} \mathrm{TPP}\right)=1.34 \cdot 10^{-5} \mathrm{~mol} / \mathrm{l}, C\left(\mathrm{O}_{2}\right)=6.59 \cdot 10^{-5} \mathrm{~mol} / \mathrm{l}\right.$, at $\left.298.15 \mathrm{~K}\right)$.

\begin{tabular}{ccc}
\hline$C(\mathrm{HCl}), \mathrm{mol} / 1$ & $k_{\mathrm{eff}} \mathrm{s}^{-1}$ & $k_{\mathrm{v}}, \mathrm{1}^{2} \cdot \mathrm{mol}^{-2} \cdot \mathrm{s}^{-1}$ \\
\hline$(1.16 \pm 0.07) \cdot 10^{-5}$ & $(1.96 \pm 0.11) \cdot 10^{-6}$ & $(2.57 \pm 0.17) \cdot 10^{3}$ \\
$(2.08 \pm 0.12) \cdot 10^{-5}$ & $(3.13 \pm 0.19) \cdot 10^{-6}$ & $(2.28 \pm 0.14) \cdot 10^{3}$ \\
$(2.73 \pm 0.17) \cdot 10^{-5}$ & $(4.47 \pm 0.29) \cdot 10^{-6}$ & $(2.49 \pm 0.15) \cdot 10^{3}$ \\
$(5.45 \pm 0.32) \cdot 10^{-5}$ & $(1.02 \pm 0.06) \cdot 10^{-5}$ & $(2.85 \pm 0.21) \cdot 10^{3}$ \\
\hline
\end{tabular}

where $k_{\mathrm{eff}}$ and $k_{\mathrm{v}}$ are the effective and veritable constants of reaction (c).

Kinetic data shown in Table 2 and Figure 1 have evidenced the first order of reaction (c) with respect to $\mathrm{HCl}$. Processing of the kinetic data obtained as varied temperature has allowed calculating the rate and equilibrium constants $K_{\text {eq }}$ (Table 3); furthermore, from the Arrhenius-type plots (Figure 2) we have succeeded in elucidation of the activation and thermodynamic parameters of reaction (c) (Table 4). We have supposed that the linear shape of the $\ln k_{v}=f\left(T^{-1}\right)$ and $\ln K_{\text {eq }}=f\left(T^{-1}\right)$ plots supports the validity of the suggested scheme of reaction (c). In order to correctly determine the equilibrium constant, we have expressed the reactants concentrations as the molar fractions. 
Table 3. Rate constants and equilibrium constants of cobalt(II) tetraphenylporphyrinate oxidation by oxygen in ethanol $\left(C\left(\mathrm{Co}^{\mathrm{II}} \mathrm{TPP}\right)=1.34 \cdot 10^{-5} \mathrm{~mol} / \mathrm{l}, C\left(\mathrm{O}_{2}\right)=6.59 \cdot 10^{-5} \mathrm{~mol} / \mathrm{l}, C(\mathrm{HCl})=\right.$ $\left.2.73 \cdot 10^{-5} \mathrm{~mol} / \mathrm{l}\right)$.

\begin{tabular}{cccc}
\hline T, K & $k_{\text {eff }} \mathrm{s}^{-1}$ & $k_{\mathrm{v}}, 1^{2} \cdot \mathrm{mol}^{-2} \cdot \mathrm{s}^{-1}$ & $K_{\text {eq }}$ \\
\hline 298.15 & $(4.47 \pm 0.29) \cdot 10^{-6}$ & $(2.49 \pm 0.15) \cdot 10^{3}$ & $(3.92 \pm 0.33) \cdot 10^{4}$ \\
303.15 & $(5.07 \pm 0.32) \cdot 10^{-6}$ & $(2.82 \pm 0.16) \cdot 10^{3}$ & $(4.18 \pm 0.34) \cdot 10^{4}$ \\
308.15 & $(5.38 \pm 0.34) \cdot 10^{-6}$ & $(2.99 \pm 0.18) \cdot 10^{3}$ & $(4.38 \pm 0.36) \cdot 10^{4}$ \\
313.15 & $(5.70 \pm 0.35) \cdot 10^{-6}$ & $(3.17 \pm 0.20) \cdot 10^{3}$ & $(4.69 \pm 0.39) \cdot 10^{4}$ \\
318.15 & $(6.19 \pm 0.38) \cdot 10^{-6}$ & $(3.44 \pm 0.23) \cdot 10^{3}$ & $(4.76 \pm 0.40) \cdot 10^{4}$ \\
\hline
\end{tabular}

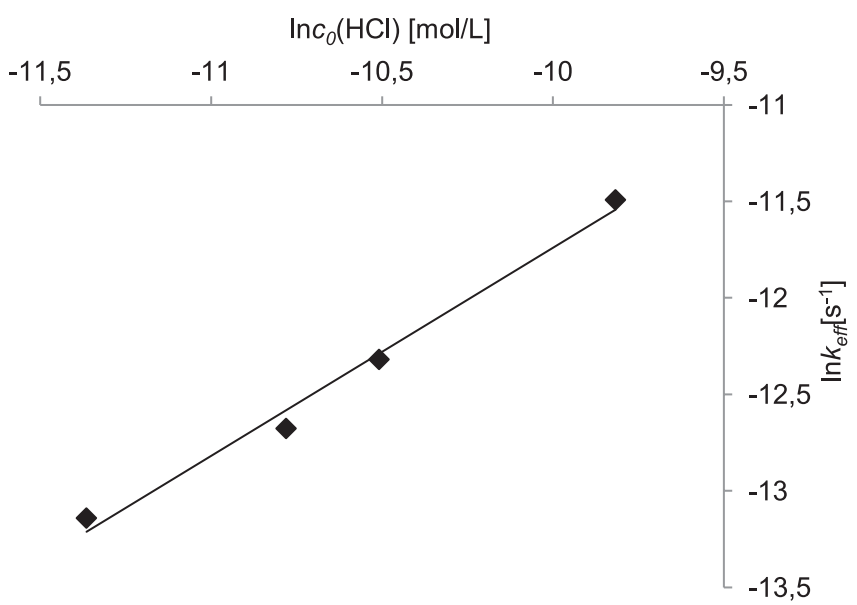

Figure 1. Effective rate constant of cobalt(II) tetraphenylporphyrinate oxidation by oxygen as function of $\mathrm{HCl}$ concentration in logarithmic coordinates $\left(C\left(\mathrm{Co}^{\text {IITPP }}\right)=1.34 \cdot 10^{-5}\right.$ $\mathrm{mol} / \mathrm{l} ; C\left(\mathrm{O}_{2}\right)=6.59 \cdot 10^{-5} \mathrm{~mol} / 1$, at $\left.298.15 \mathrm{~K}\right)$.

The low value of activation entropy of the studied reaction (Table 2) was likely due to the nature of $\mathrm{Co}^{\mathrm{II}} \mathrm{TPP}$ interaction with oxygen: the both reactants were molecules bearing the unpaired electrons at the reactive site. ${ }^{[14-16]}$ The high negative activation entropy was also expected taking into consideration binding of oxygen at the metal ion in the
Table 4. Activation and thermodynamic parameters of reaction (c) at $298.15 \mathrm{~K}$

\begin{tabular}{ccccc}
\hline$k_{\mathrm{v}} \times 10^{-3}, 1^{2} \cdot \mathrm{mol}^{-2} \cdot \mathrm{s}^{-1}$ & $\Delta G^{\#}, \mathrm{~kJ} / \mathrm{mol}$ & $\Delta H^{\sharp}, \mathrm{kJ} / \mathrm{mol}$ & $\Delta S^{\#}, \mathrm{~J} \cdot \mathrm{mol}^{-1} \cdot \mathrm{K}^{-1}$ \\
\hline $2.49 \pm 0.15$ & $53.6 \pm 2.5$ & $9.7 \pm 0.7$ & $-147 \pm 19$ \\
\hline$E_{\mathrm{a}}, \mathrm{kJ} / \mathrm{mol}$ & $K_{\mathrm{eq}} \times 10^{-4}$ & $\Delta G^{\mathrm{o}}, \mathrm{kJ} / \mathrm{mol}$ & $\Delta H^{\mathrm{o}}, \mathrm{kJ} / \mathrm{mol}$ & $\Delta S^{\mathrm{o}}, \mathrm{J} \cdot \mathrm{mol}^{-1} \cdot \mathrm{K}^{-1}$ \\
\hline $12.2 \pm 0.7$ & $3.92 \pm 0.33$ & $-26.2 \pm 4.2$ & $8.0 \pm 0.6$ & $115 \pm 16$ \\
\hline
\end{tabular}

transition state. The thermodynamic parameters of reaction (c) (Table 2) could not be easily interpreted, possibly, due to the different conditions of the starting reagents and the products solvation.

Acknowledgements. This work was financially supported by Russian Foundation for Basic Research (project no. 1423-00204). The authors are grateful to Dr. Zhurko G.A. for his help.

\section{References}

1. Ji H.-B., Zhou X.-T. Biomimetic Epoxidation of Olefins Catalyzed by Metalloporphyrins with Molecular Oxygen. In: Biomimetic Based Application (George A., Ed.), InTech, 2011. pp. 1-30.

2. Berezin D.B. The Macrocyclic Effect and Structural Chemistry of Porphyrins, Moscow: Krasand, 2010. 424 p. (in Russ.) [Березин Д.Б. Макрочиклический эффект и структурная химия порфиринов, М.: КРАСАНД, 2010. 424 с.].

3. Aleksandriiskii V.V., Islyaikin M.K., Burmistov V.A., Syrbu S.A. Macroheterocycles 2009, 2, 52-56.

4. Ziyadova T.M., Burmistrov V.A., Semeikin A.S., Koifman O.I. Izv. Vyssch. Uchebn. Zaved., Khim. Khim. Tekhnol. 2013, 11, 48-50 (in Russ.).

5. Ocheretovyi A.S., Trifonova I.P. Izv. Vyssch. Uchebn. Zaved., Khim. Khim. Tekhnol. 2007, 2, 20-22 (in Russ.).

6. Shmid R., Sapunov V.N. Informal Kinetics, Moscow: Mir, 1985 264 р. (in Russ.) [Шмид Р., Сапунов В.Н. Неформальная кинетика, М.: Мир, 1985. 264 с.].

7. Koifman O.I., Ageeva T.A. Structural Types of Porphyrins In: Advances in Porphyrin Chemistry, Vol. 1, St.-Petersburg, 1997. pp. 6-26 (in Russ.) [Койфман О.И., Агеева Т.A.
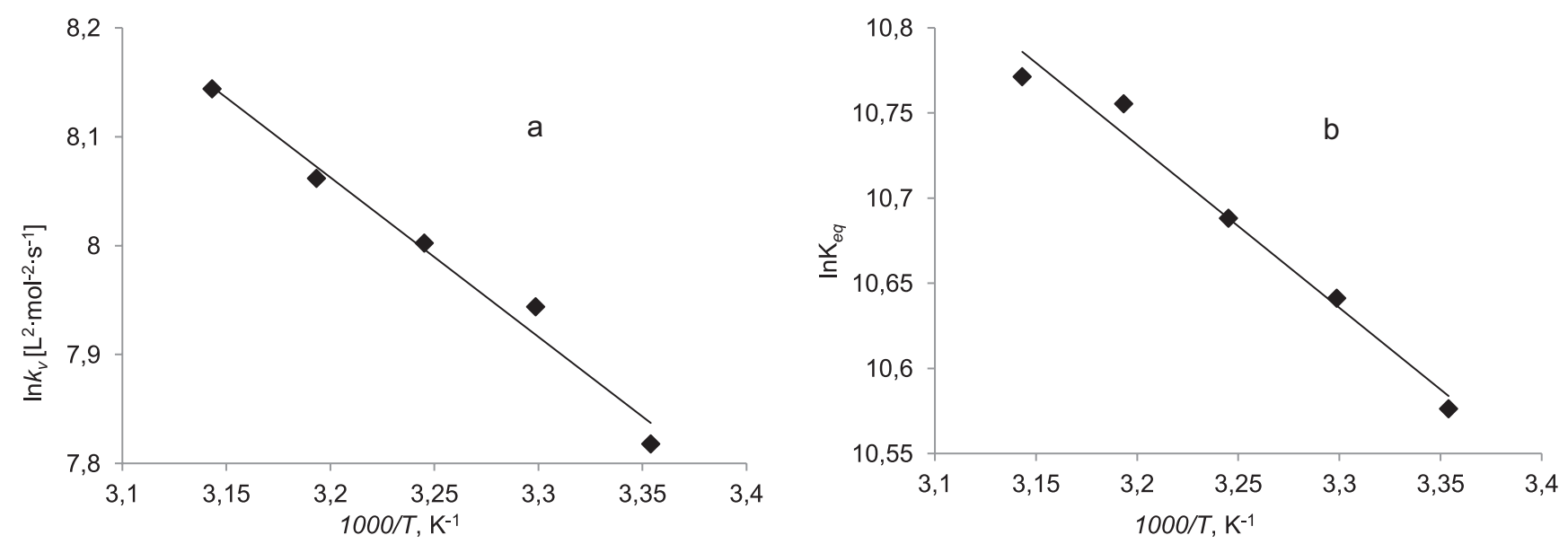

Figure 2. Logarithms of the rate constant (a) and equilibrium constant (b) of cobalt(II) tetraphenylporphyrinate oxidation by oxygen as functions of reciprocal temperature. 
Oxidation of Cobalt(II) Tetraphenylporphyrinate with Molecular Oxygen

Структурные типы порфиринов. В кн.: Успехи химии порфиринов, Т. 1, СПб: НИИ химии СПбГУ, 2001. с. 6-26].

8. Goronovskii I.T., Nazarenko Yu.P., Nekryach E.F. Summary Reference for Chemistry, Kiev: Naukova dumka, 1974. 992 p. (in Russ.) [Гороновский И.Т., Назаренко Ю.П., Некряч Е.Ф. Краткий справочник по химии, Киев: Наукова думка, 1974. 992 c.].

9. Kolker A.M., Safonova L.P. In: Conductometry. Experimental Methods of Solution Chemistry, Moscow: Nauka, 1997. pp. 91-140 (in Russ.) [Колкер А.М., Сафонова Л.П. В кн.: Кондуктометрия. Экспериментальные методы химии растворов, М.: Наука, 1997. 91-140].

10. Trifonova I.P., Burmistrov V.A., Syrbu S.A., Koifman O.I. Russ. J. Gen. Chem. 2005, 8, 1290-1294.
11. Hoffman M.R., Hong A.P.K. Sci. Total Environ. 1987, 64, 99-115.

12. Loas A., Gerdes R., Zhang Y., Gorun S.M. Dalton Trans. 2011, 40, 5162-5165.

13. Zwart J., Van Der Weide H.C., Bröker N., Rummens C., Schuit G.C.A. J. Mol. Catal. 1977, 3, 151-163.

14. $N_{4}$-Macrocyclic Metal Complexes (Zagal J.H., Bedioui F., Dodelet J.-P., Eds.), New York: Springer Science+Business Media, 2006. 814 p

15. Walker F.A. Proton NMR and EPR Spectroscopy of Paramagnetic Metalloporphyrins. In: The Porphyrin Handbook, Vol. 5 (Kadish K.M., Smith K.M., Guilard R., Eds.), San Diego: Academic Press, 2000. pp. 81-183.

16. Cui W., Li S., Wayland B.B. J. Organomet. Chem. 2007, 692, 3198-3206.

Received 19.09.2014

Received revised 13.05.2015

Accepted 19.05.2015 